\title{
Analisis Pengaruh Modal Bank, Ukuran Bank, Konsentrasi Pasar, Kepemilikan, Inflasi Terhadap Profitabilitas Bank
}

\author{
Serly $^{1 *}$, Jennifer $^{2}$ (iD) \\ ${ }^{123}$ Program Studi Akuntansi, Fakultas Ekonomi, Universitas Internasional Batam, Indonesia \\ *serly.uib@gmail.com ${ }^{\text {* }}$
}

\section{Abstrak}

Penelitian ini memiliki tujuan yaitu mengetahui bagaimana pengaruh dari modal bank, ukuran bank, konsentrasi pasar, kepemilikan, inflasi terhadap profitabilitas bank. Metode yang dipakai dalam penelitian yaitu analisis regresi data panel dan menggunakan data sekunder dan data yang dibutuhkan peneliti diperoleh dari laporan perusahaan terbuka yang bergerak di bidang perbankan di Indonesia dan terdaftar di BEI (Bursa Efek Indonesia) dengan jangka waktu 2016-2020. Hasil penelitian memperlihatkan bahwa modal bank tidak mempunyai pengaruh signifikan terhadap profitabilitas bank, ukuran bank mempunyai pengaruh positif dan signifikan terhadap profitabilitas bank, konsentrasi pasar tidak mempunyai pengaruh signifikan terhadap profitabilitas bank, kepemilikan tidak mempunyai pengaruh signifikan terhadap profitabilitas bank, dan inflasi mempunyai pengaruh positif dan signifikan terhadap profitabilitas bank.

Keywords: Profitabilitas Bank, Karakteristik Internal, Struktur Industri, Situasi Ekonomi

\section{Abstract}

The purpose of this study is to determine the effect of bank capital, bank size, concentration, ownership, inflation on bank profitability. The method that is used by this study is panel data regression analysis method and this study uses secondary data and the data needed by researchers is obtained from the reports of public companies engaged in banking in Indonesia and listed on the IDX (Indonesian Stock Exchange) during the 2016-2020 period. The results of the study stated that bank capital had no significant effect on bank profitability, bank size had a positive and significant effect on bank profitability, market concentration had no significant effect on bank profitability, ownership had no significant effect on bank profitability, and inflation had a positive and significant effect on bank profitability.

Keywords: Bank Profitability, Internal Characteristic, Industry Structure, Economy Situation

\section{Pendahuluan}

Bank merupakan salah satu faktor penting untuk perkembangan ekonomi suatu Negara. Bank berjalan dengan cara menerima dan menyimpan uang dari masyarakat dan menyalurkannya kembali kepada mereka melalui pinjaman kredit. Di masa sekarang, masyarakat sudah banyak menggunakan jasa bank untuk melakukan berbagai macam transaksi keuangan. Agar bank tersebut bisa berjalan, tingkat profitabilitas bank tersebut berperan penting dalam kelangsungan bank tersebut. Tingkat profitabilitas bank dapat mempengaruhi tingkat loyalitas nasabah. Apabila bank bisa melakukan kegiatannya dengan efisien, maka keuntungan yang dapat diterima oleh bank akan meningkat, dan bank dapat memberikan fasilitas kredit yang lebih banyak kepada nasabah sehingga pada akhirnya akan meningkatkan kinerja keuangan dan keuntungan bank.

History:
Received: August 2021
Revised: Oktober 2021
Accepted: November 2021
Published: November 2021

Publisher: Undiksha Press

Licensed: This work is licensed under

a Creative Commons Attribution 3.0 License

Published: November 2021 
Mengingat pentingnya peran bank untuk perekonomian negara serta dampak ekonomi yang bisa terjadi jika suatu perusahaan perbankan gagal, maka perlu dilaksanakan serangkaian analisis agar dapat menemukan permasalahan di industri perbankan, supaya dapat mengantisipasi kegagalan bank dan dapat menjaga tingkat kesehatan bank. Analisis yang dapat dilakukan adalah melalui analisis dan perhitungan rasio kinerja keuangan. Dengan menganalisis laporan keuangan, perusahaan dapat memperoleh informasi tentang status keuangan perusahaan dan hasil-hasil yang terkait dengan pilihan strategis perusahaan untuk diterapkan. Pimpinan perusahaan dapat memahami pencapaian masa lalu dan saat ini, memahami status perusahaan dan perkembangan keuangan. Manajemen kemudian dapat mengatasi permasalahan dengan mengambil langkah-langkah yang diperlukan. Dan indikator yang paling tepat adalah ROA (return on asset) (Pinasti \& Mustikawati, 2018).

Profitabilitas bank sangat penting untuk diteliti karena banyaknya bank swasta yang berdiri saat ini sehingga persaingan semakin ketat dan bank perlu mempertahankan tingkat profitabilitasnya. Di masa pandemi ini ada banyak sekali usaha-usaha yang terpaksa berhenti karena halangan ekonomi yang terjadi karena tidak ada konsumen. Tak terkecuali juga untuk bank di mana perekonomian bank sangat tergantung pada nasabahnya kemudian karena bisnis nasabah bank banyak juga yang terpengaruh oleh virus Covid-19.

\section{ROA}

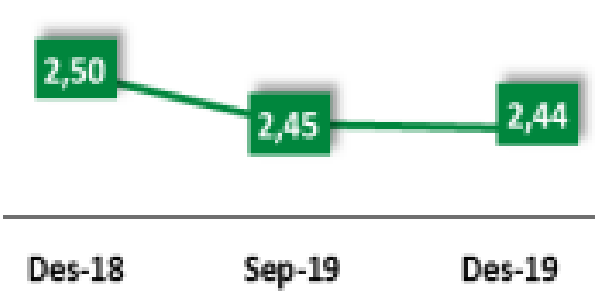

Gambar 1. Grafik ROA Sebelum Pandemi Covid-19

\section{CAR \& ROA}

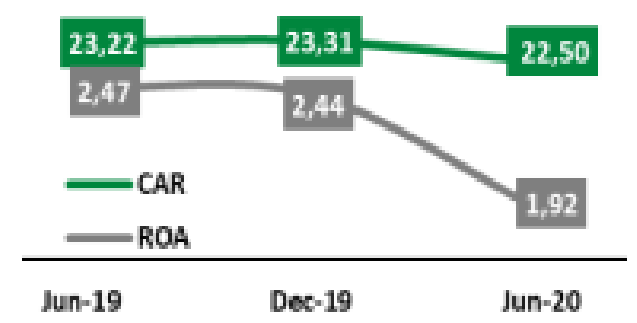

Gambar 2. Grafik ROA Setelah Pandemi Covid-19

Rasio ROA semakin menurun karena nasabah tidak mampu membayar angsurannya yang membuat kesehatan bank semakin berkurang. Deposito juga mulai dicairkan untuk menyelamatkan bisnis atau untuk kebutuhan sehari-hari yang menyebabkan bank kekurangan dana. Kemudian tingkat suku bunga yang dijamin LPS semakin menurun menyebabkan suku bunga yang bisa ditawarkan kepada nasabah kurang menarik. Peneliti ingin meneliti tentang analisis pengaruh modal bank, ukuran bank, konsentrasi pasar, kepemilikan, dan inflasi terhadap profitabilitas bank karena banyaknya persaingan antar bank dalam kondisi saat ini dan supaya bank bisa berjalan dengan efisien dan juga mengambil keputusan dengan benar untuk meningkatkan profitabilitas bank tersebut. 
Faktor pertama yang dapat mempengaruhi profitabilitas bank yaitu modal bank. Yaitu jumlah dana yang digunakan untuk mendirikan perusahaan, mendanai kegiatan di dalam perusahaan dan dihitung dengan cara total asset minus liabilities. Bank adalah lembaga perantara yang bertujuan untuk memperoleh keuntungan. Sebagai bank, mereka mengumpulkan uang dari unit surplus dan mendistribusikan ke unit defisit, dan bank mendapatkan keuntungan dari margin tersebut. Lee et al.,(2015) Menggunakan data panel untuk 171 bank komersial Cina dari tahun 1997 hingga 2011 dan menganalisa pengaruh modal bank terhadap profitabilitas, dan menemukan hubungan positif yang signifikan antara modal dan profitabilitas. Sedangkan studi yang dilakukan oleh Batten dan Xuun Vinh, (2017) menyatakan bahwa modal bank tidak mempengaruhi profitabilitas.

Faktor berikutnya yang juga mempengaruhi profitabilitas bank yaitu ukuran bank. Yaitu ukuran perusahaan berupa aset perusahaan yang juga menggambarkan kesehatan suatu bank, dapat dihitung dari total asset bank tersebut baik tangible maupun intangible asset. Ada sejumlah indeks untuk mengukur ukuran bank yang ditemukan dalam literatur perbankan. Mereka adalah total aset, jumlah simpanan, dan total pinjaman. Lee et al., (2015)menemukan hubungan yang positif antara ukuran bank dengan profitabilitas dimana dibandingkan dengan bank kecil, bank besar memiliki profitabilitas yang lebih tinggi.

Faktor selanjutnya yang mempengaruhi profitabilitas bank yaitu konsentrasi pasar. Mencerminkan distribusi pasar di antara perusahaan yang berbeda dan mewakili dua aspek yaitu jumlah perusahaan dan ketidaksetaraan dalam distribusi pangsa pasar di antara perusahaan. Konsentrasi pasar memperlihatkan perilaku kolusi dan mengarahkan kekuatan pasar untuk mendapatkan keuntungan yang lebih besar. Oleh karena itu, penelitian ini menganggapankan bahwa semakin terkonsentrasi suatu bank maka semakin besar market power yang meningkat melalui HHI dan semakin memimpin peningkatan rasio ROA(Abbas \& Arizah, 2019). Konsentrasi pasar memperlihatkan tingkat daya saing di industri(Gaur \& Mohapatra, 2020). Bank dengan konsentrasi pasar tinggi lebih menguntungkan: mereka memiliki return on asset (ROA) yang lebih tinggi, margin bunga bersih (NIM) dan kekuatan pendapatan berulang (REP) sedangkan bank dengan konsentrasi pasar tersebar memiliki pengembalian ekuitas (ROE) yang lebih tinggi(Peterson Kitakogelu Ozili \& Uadiale, 2017). Sedangkan studi yang dilakukan De Haan dan Poghosyan, (2012) memperlihatkan bahwa semakin tinggi konsentrasi pasar, semakin rendah pula profitabilitas bank.

Faktor selanjutnya yaitu kepemilikan. Bank dibagi menjadi beberapa kepemilikan. Ciriciri kepemilikan masing-masing memperlihatkan bahwa semakin banyak jenis kepemilikan dalam perusahaan, artinya cara perusahaan beroperasi ke arah kepemilikan saham terbesar(Fathinna et al., 2016). Kepemilikan bank mempengaruhi distribusi saham dan prosedur pengelolaan dana(peraturan yang ditetapkan oleh pemegang kepemilikan terbesar). Hasil studi Mohammad Morshedur Rahman et al., (2015) memperlihatkan bahwa kepemilikan berhubungan negatif dengan ROA yang memperlihatkan bahwa bank umum swasta memiliki kecenderungan untuk memiliki profitabilitas yang lebih rendah daripada bank milik pemerintah yang sebanding.

Inflasi juga mempengaruhi profitabilitas bank, dimana inflasi merupakan kenaikan harga secara keseluruhan yang bisa menyebabkan terganggunya kesimbangan antara arus uang \& barang. Inflasi terjadi di karenakan adanya inflasi pada luar negeri yang menyebabkan naiknya harga barang pada dalam negeri. Nilai inflasi yang tinggi akan mengakibatkan menurunnya pendapatan riil rakyat sehingga sebagai akibatnya standar hidup rakyat turut menurun, yang menyebabkan kemungkinan debitur tidak bisa membayar cicilan kreditnya(Tiwu, 2020). Sebagian besar penelitian telah melaporkan hubungan yang positif. Namun, tingkat inflasi yang tidak terduga dapat menyebabkan biaya tinggi dan profitabilitas yang lebih rendah. Sehingga secara teoritis, efeknya juga saling bertentangan(Bolarinwa et 
al., 2019). Berdasarkan studi yang dilakukan oleh Lee dan Hsieh, (2013) inflasi memiliki pengaruh negatif terhadap profitabilitas.

Karena hasil beberapa penelitian terdahulu di atas yang tidak konsisten, maka akan dilakukan penelitian dengan judul "Analisis Pengaruh Modal Bank, Ukuran Bank, Konsentrasi Pasar, Kepemilikan, Inflasi Terhadap Profitabilitas Bank".

Tujuan dari penelitian ini yaitu : (1) untuk mengetahui apakah modal bank memiliki pengaruh terhadap profitabilitas bank. (2) untuk mengetahui apakah ukuran bank memiliki pengaruh terhadap profitabilitas bank. (3) untuk mengetahui apakah konsentrasi pasar memiliki pengaruh terhadap profitabilitas bank. (4) untuk mengetahui apakah kepemilikan memiliki pengaruh terhadap profitabilitas bank. (5) untuk mengetahui apakah inflasi memiliki pengaruh terhadap profitabilitas bank.

Bank dengan permodalan yang memadai menikmati stabilitas dan dapat dengan mudah menahan masalah seperti hutang yang ditangguhkan dan guncangan ekonomi lainnya atau mencegah perkembangan guncangan yang berlebihan. Jumlah modal juga mempengaruhi kapasitas pinjaman bank. Hasil dari penelitian yang dilakukan Ebrahimi et al., (2016) memperlihatkan bahwa profitabilitas bank dipengaruhi secara positif oleh permodalan. Berdasarkan rincian diatas, maka hipotesis dapat dirumuskan:

$\mathrm{H}_{1}$ : Modal bank memiliki pengaruh positif dan signifikan terhadap profitabilitas bank.

Sebuah bank besar yang diukur dengan total aset atau total pinjaman atau total simpanan dapat menikmati skala ekonomi atau diseconomies(Samad, 2015). Ukuran bank diukur dengan logaritma natural dari total aset. Hubungan yang positif diharapkan antara ukuran bank dan profitabilitas karena bank-bank besar lebih mampu mendiversifikasi aktivitasnya dan sebagai konsekuensinya meningkatkan pendapatannya (Bougatef, 2017). Berdasarkan penelitian Peterson K Ozili, (2018) semakin besar sektor perbankan, semakin tinggi kedalaman dan/atau keluasan intermediasi keuangan dalam sistem keuangan suatu negara. Asalkan kerangka peraturan risiko sistemik yang kuat ada, sektor perbankan besar seharusnya relatif lebih stabil dibandingkan dengan sektor perbankan kecil; karenanya, diharapkan ada hubungan positif antara stabilitas perbankan dan ukuran sektor perbankan. Berdasarkan rincian diatas, maka hipotesis dapat dirumuskan:

$\mathrm{H}_{2}$ : Ukuran bank memiliki pengaruh positif dan signifikan terhadap profitabilitas bank.

Konsentrasi pasar berpengaruh positif terhadap profitabilitas bank. Terjadinya penurunan atau kenaikan konsentrasi pasar akan mengakibatkan penurunan suku bunga dan kenaikan suku bunga. Selain itu, peningkatan jumlah bank meningkatkan kemungkinan menerima pinjaman oleh pelanggan yang tidak memadai dan oleh karena itu menurunkan profitabilitas bank (Ebrahimi et al., 2016). Studi yang dilakukan Peterson K Ozili, (2018) memperlihatkan bahwa konsentrasi pasar berpengaruh signifikan positif terhadap profitabilitas bank. Berdasarkan rincian diatas, maka hipotesis dapat dirumuskan:

$\mathrm{H}_{3}$ : Konsentrasi pasar memiliki pengaruh positif dan signifikan terhadap profitabilitas bank.

Kepemilikan bank merupakan variabel yang dapat menjelaskan struktur pasar industri perbankan. Kepemilikan dapat menjelaskan perbedaan kinerja sistem perbankan swasta dan publik. Masuknya bank swasta dengan demikian dapat meningkatkan profitabilitas sistem perbankan (Ebrahimi et al., 2016). Hasil studi Mohammad Morshedur Rahman et al., (2015) memperlihatkan bahwa kepemilikan berhubungan negatif dengan ROA yang memperlihatkan bahwa bank umum swasta memiliki kecenderungan untuk memiliki profitabilitas yang lebih rendah daripada bank milik pemerintah yang sebanding. Berdasarkan rincian diatas, maka hipotesis dapat dirumuskan:

$\mathrm{H}_{4}$ : Kepemilikan memiliki pengaruh negatif dan signifikan terhadap profitabilitas bank.

Tingkat inflasi tinggi yang tidak terduga dapat menurunkan profitabilitas bank, terutama jika tidak diproyeksikan oleh pengelola bank. Di sisi lain, tingkat inflasi yang tinggi 
mengimplikasikan terjadinya ledakan ekonomi sehingga meningkatkan kegiatan ekonomi termasuk permintaan pinjaman bank (Bolarinwa \& Soetan, 2019). Sebagian besar penelitian telah melaporkan hubungan yang positif. Berdasarkan rincian diatas, maka hipotesis dapat dirumuskan:

$\mathrm{H}_{5}$ : Inflasi memiliki pengaruh positif dan signifikan terhadap profitabilitas bank.

\section{Metode}

Penelitian ini merupakan penelitian yang bersifat deskriptif, di mana peneliti mengumpulkan, menganalisis, dan menyajikan data yang dikumpulkan. Penelitian juga bersifat kausal komparatif untuk menjelaskan hubungan antar variabel penelitian di mana variabel bebas dalam penelitian ini yaitu modal bank, ukuran bank, konsentrasi pasar, kepemilikan, dan inflasi. Variabel dependen yang dipakai dalam penelitian ini adalah profitabilitas bank. Objek penelitian yang dipakai dalam penelitian ini yaitu perusahaan yang terdaftar sebagai perusahaan terbuka dan tercatat di dalam Bursa Efek Indonesia dan kriteria pengambilan sampel yaitu (1) perusahaan terbuka yang terdaftar di Bursa Efek Indonesia untuk perbankan antara tahun 2016 dan 2020, dan (2) laporan keuangan tahunan di tanggal 31 Desember. Data yang terkumpul diuji dengan memakai software Statistical Product and Service Solution versi 25 untuk Windows.

\section{Hasil dan Pembahasan}

Hasil dari pengujian penelitian yang datanya bersumber dari pencatatan dokumen laporan tahunan perusahaan yang berjumlah 181 data adalah sebagai berikut. Hasil pengujian uji statistik deskriptif memperlihatkan bahwa variabel modal bank memiliki nilai minimum senilai 139.051 yaitu dari Bank Artos Indonesia, nilai maksimum senilai 292.496.755 yaitu dari Bank Mandiri, nilai rata-rata (mean) senilai 30.676.638,79, dan nilai standar deviasi senilai 58.781.518,65. Variabel ukuran bank memiliki nilai minimum senilai 13,64 yaitu Bank Artos Indonesia, nilai maksimum senilai 21,14 yaitu dari Bank Rakyat Indonesia, nilai mean senilai 17,50, dan nilai standar deviasi senilai 1,80. Variabel kepemilikan memiliki nilai minimum 0 , nilai maksimum 1 , mean 0,37 , dan standar deviasi 0,41 . Variabel konsentrasi pasar memiliki nilai minimum senilai 0,00 (Bank Mestika Dharma), nilai maksimum senilai 1,00 (Bank Bisnis Internasional), nilai mean 0,85, serta standar deviasi senilai 0,36 . Variabel inflasi memiliki nilai minimum 0,02 , nilai maksimum 0,04 , nilai mean 0,85 , serta nilai standar deviasi 0,36 .

Untuk mengetahui normal tidaknya pendistribusian data dapat dilakukan uji normalitas data dengan menggunakan uji Kolmogorov-Smirnov. Apabila angka signifikansi Asymp. Sig. $>0,05$ hal ini berarti data penelitian berdistribusi normal, dan apabila angka signifikansi Asymp. Sig. $<0,05$ berarti data penelitian tidak berdistribusi normal. Berdasarkan hasil pengujian diperoleh nilai signifikansi sebesar 0,200. Didapatkan hasil bahwa data penelitian ini berdistribusi normal karena nilai signifikansinya $>0,05$.

Tabel 1. Uji Normalitas

\begin{tabular}{llr}
\hline & & Unstandardized Residual \\
\hline $\mathrm{N}$ & & 181 \\
\hline \multirow{2}{*}{ Normal Parameters ${ }^{a, b}$} & Rata-rata & 0,0000000 \\
\cline { 2 - 3 } & Standar Deviasi & 0,00660171 \\
\hline \multirow{2}{*}{ Most Extreme Differences } & Absolut & 0,046 \\
\cline { 2 - 3 } & Positif & 0,046 \\
\cline { 2 - 3 } & Negatif & $-0,28$ \\
\hline Kolmogorov-Smirnov Z & & 0,046 \\
\hline Asymp. Sig. (2-tailed) & & 0,200 \\
\hline Sumber: Data diolath
\end{tabular}

Sumber: Data diolah, 2021 
Uji multikolinearitas dilakukan untuk mengetahui terjadi tidaknya multikolinearitas di model regresi. Dikarenakan nilai toleransi dari hasil pengujian $>0,1$ dan mempunyai nilai VIF $<10$, maka dapat ditarik kesimpulan dari tabel berikut bahwa penelitian ini tidak terjadi multikolinearitas.

Tabel 2. Uji Multikolinearitas

\begin{tabular}{lccl}
\hline \multirow{2}{*}{ Model } & \multicolumn{2}{c}{ Collinearity Statistics } & \\
\cline { 2 - 3 } & Toleransi & VIF & \multirow{2}{*}{ Keterangan } \\
\hline Modal Bank & 0.473 & 2.112 & Bebas Multikolinearitas \\
\hline Ukuran Bank & 0.420 & 2.382 & Bebas Multikolinearitas \\
\hline Konsentrasi Pasar & 0.949 & 1.054 & Bebas Multikolinearitas \\
\hline Kepemilikan & 0.842 & 1.188 & Bebas Multikolinearitas \\
\hline Inflasi & 0.988 & 1.012 & Bebas Multikolinearitas \\
\hline
\end{tabular}

Sumber: Data diolah, 2021

Uji autokorelasi yaitu pengujian untuk mengevaluasi apakah terjadi korelasi antara kesalahan pengganggu dalam model regresi selama suatu periode dengan kesalahan pengganggu selama periode sebelumnya. Fungsinya untuk menentukan daerah yang memiliki autokorelasi positif atau negatif dan menjelaskan apakah terdapat autokorelasi. Berdasarkan gambar 3 di bawah ini hasil uji autokorelasi menggunakan Durbin Watson, didapatkan hasil bahwa penelitian ini tidak terjadi autokorelasi karena nilai Durbin Watson tercapai sebesar 1,340, yang artinya nilai Durbin Watson $-2<1,340<2$.

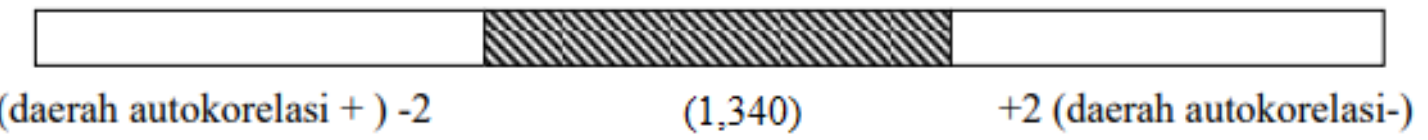

Gambar 3. Uji Autokorelasi

Uji heteroskedastisitas yaitu pengujian untuk mendeteksi terjadi atau tidaknya heteroskedastisitas dan varian residual tidak terdapat persamaan untuk satu pengamatan ke pengamatan lainnya. Terjadi tidaknya heteroskedastisitas dapat diketahui dari diagram yang telah diuji antara variabel dependen dengan residualnya, dimana apabila dalam diagram tersebut tidak terjadi pembentukan suatu pola dan titik-titik penyebaran berada di atas dan di bawah nilai 0 pada sumbu $\mathrm{Y}$, maka penelitian tersebut tidak terjadi heteroskedastisitas. Gambar 4 dibawah ini memperlihatkan hasil uji dimana titik-titik terdistribusi secara acak di atas dan di bawah angka 0 dan pada sumbu Y. Oleh karena itu, heteroskedastisitas tidak terjadi dalam penelitian ini.

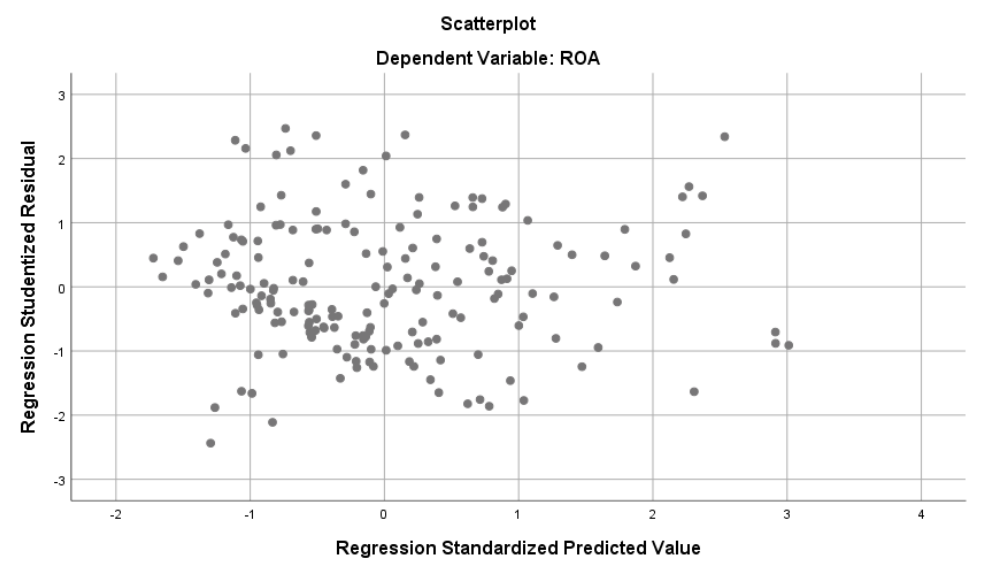

Gambar 4. Uji Heteroskedastisitas 
Uji Koefisien determinasi (R2) yaitu pengujian yang berfungsi untuk memperlihatkan tingkat pengaruh variabel independen terhadap variabel terikat. Hasil uji memperlihatkan nilai R2 senilai 0,434 . Hal ini memperlihatkan bahwa variabel bebas berpengaruh sebesar 43\% terhadap variabel dependen sedangkan $57 \%$ dipengaruhi oleh variabel lain yang tidak termasuk di dalam model regresi linear.

Tabel 3. Uji Koefisien Determinasi

\begin{tabular}{|c|c|c|c|c|}
\hline Model & $\mathbf{R}$ & $R$ Square & Adjusted R Square & Std. Error of the Estimate \\
\hline 1 & $0,658^{\mathrm{a}}$ & 0,434 & 0,417 & 0,00670 \\
\hline
\end{tabular}

Sumber: Data diolah, 2021

Untuk berfungsi untuk mengetahui apakah terdapat pengaruh dan hubugan antara variabel bebas yaitu modal bank, ukuran bank, konsentrasi pasar, kepemilikan dan inflasi terhadap variabel terikat yaitu profitabilitas bank maka harus dilakukan uji regresi linier berganda. Berdasarkan tabel 4 di bawah ini mendapatkan model persamaan sebagai berikut.

$Y=-0,47+3,211 X_{1}+0,003 X_{2}+0,001 X_{3}+0,003 X_{4}+0,311 X_{5}$

Interpretasi hasil uji yang terdapat pada tabel 4 dibawah ini dapat dijabarkan sebagai berikut. (1) Konstanta senilai $-0,47$ artinya apabila modal bank (X1), ukuran bank (X2), konsentrasi pasar (X3), kepemilikan (X4), dan inflasi (X5) nilainya sama dengan nol, maka nilai dari profitabilitas bank (Y) senilai -0,47. (2) Nilai koefisien modal bank ( $\beta 1$ ) senilai 3,211 berpengaruh positif terhadap profitabilitas bank (Y). Yang berarti setiap kenaikan nilai modal bank (X1) senilai satu satuan, maka nilai profitabilitas bank (Y) akan mengalami kenaikan senilai 2,741 dengan anggapan bahwa variabel bebas yang lainnya tidak berubah. (3) Nilai koefisien ukuran bank $(\beta 2)$ senilai 0,003 berpengaruh positif terhadap profitabilitas bank (Y). Yang berarti setiap kenaikan nilai ukuran bank (X2) senilai satu satuan, nilai profitabilitas bank (Y) akan mengalami penyusutan senilai 0,467 dengan anggapan bahwa variabel independen yang lainnya tetap. (4) Nilai koefisien konsentrasi pasar ( $\beta 3$ ) senilai 0,001 berpengaruh positif terhadap profitabilitas bank (Y). Yang berarti setiap kenaikan nilai konsentrasi pasar (X3) senilai satu satuan, nilai profitabilitas bank (Y) akan mengalami penyusutan senilai 0,469 dengan anggapan bahwa variabel independen yang lainnya tetap. (5) Nilai koefisien kepemilikan $(\beta 4)$ senilai 0,003 berpengaruh positif terhadap profitabilitas bank (Y). Yang berarti setiap kenaikan nilai kepemilikan (X4) senilai satu satuan, nilai profitabilitas bank (Y) akan mengalami penyusutan senilai 0,467 dengan anggapan bahwa variabel independen yang lainnya tetap. (6) Nilai koefisien Inflasi ( $\beta 5$ ) senilai 0,311 berpengaruh positif terhadap profitabilitas bank (Y). Yang berarti setiap kenaikan nilai Inflasi (X5) senilai satu satuan, nilai profitabilitas bank (Y) akan mengalami penyusutan senilai 0,159 dengan anggapan bahwa variabel independen yang lainnya tetap.

Tabel 4. Uji Regresi Linier Berganda

\begin{tabular}{llccc}
\hline \multirow{2}{*}{ Model } & \multicolumn{2}{c}{ Unstandardized Coefficients } & Standardized Coefficient \\
\cline { 3 - 5 } & \multirow{2}{*}{1} & \multicolumn{1}{c}{$\boldsymbol{B}$} & Std. Error & Beta \\
\hline & (Constant) & $-0,047$ & 0,008 & \\
\cline { 2 - 5 } & Modal Bank & 3,211 & 0,000 & 0,215 \\
\cline { 2 - 5 } & Ukuran Bank & 0,003 & 0,000 & 0,514 \\
\cline { 2 - 4 } & Konsentrasi Pasar & 0,001 & 0,001 & 0,047 \\
\cline { 2 - 4 } & Kepemilikan & 0,003 & 0,002 & 0,117 \\
\cline { 2 - 4 } & Inflasi & 0,311 & 0,080 & 0,224 \\
\hline
\end{tabular}

Sumber: Data diolah, 2021 
Untuk mengetahui pengaruh modal bank, ukuran bank, konsentrasi pasar, kepemilikan dan inflasi terhadap profitabilitas bank secara parsial, harus dilakukan uji t. Berdasarkan tabel 5 di bawah ini, hasil dari uji $t$ adalah sebagai berikut. (1) variabel modal bank memiliki nilai signifikansi uji t senilai 0,010, dikarenakan nilai tersebut > 0,05 maka H1 ditolak. Hasilnya yaitu modal bank tidak mempunyai pengaruh signifikan terhadap profitabilitas bank. (2) variabel ukuran bank memiliki nilai signifikansi uji t senilai 0,000, dikarenakan nilai tersebut $<0,05$ maka $\mathrm{H} 2$ diterima. Hasilnya yaitu ukuran bank mempunyai pengaruh positif dan signifikan terhadap profitabilitas bank. (3) variabel konsentrasi pasar memiliki nilai signifikansi uji t senilai 0,418 , dimana nilai tersebut $>0,05$ sehingga $\mathrm{H} 3$ ditolak. Hasilnya yaitu konsentrasi pasar tidak memiliki pengaruh signifikan terhadap profitabilitas bank. (4) variabel kepemilikan memiliki nilai signifikansi uji t senilai 0,060, dimana nilai tersebut > 0,05 sehingga $\mathrm{H} 4$ ditolak. Hasilnya yaitu kepemilikan tidak memiliki pengaruh signifikan terhadap profitabilitas bank. (5) variabel inflasi memiliki nilai signifikansi uji t senilai 0,000, dimana nilai tersebut $<0,05$ sehingga H5 diterima. Hasilnya yaitu inflasi mempunyai pengaruh positif dan signifikan terhadap profitabilitas bank.

Tabel 5. Uji t

\begin{tabular}{llcc}
\hline & Model & \multicolumn{1}{c}{$\boldsymbol{t}$} & Sig. \\
\hline \multirow{3}{*}{1} & $($ constant $)$ & $-5,689$ & 0,000 \\
\cline { 2 - 4 } & Modal Bank & 2,602 & 0,010 \\
\cline { 2 - 4 } & Ukuran Bank & 5,859 & 0,000 \\
\cline { 2 - 4 } & Konsentrasi Pasar & 0,811 & 0,418 \\
\cline { 2 - 4 } & Kepemilikan & 1,893 & 0,060 \\
\cline { 2 - 4 } & Inflasi & 3,907 & 0,000 \\
\hline
\end{tabular}

Sumber: Data diolah, 2021

Untuk mengetahui apakah variabel independen memiliki pengaruh secara keseluruhan terhadap variabel terikat, akan dilakukan uji f dan hasil uji penelitian memperlihatkan bahwa variabel bebas memiliki pengaruh signifikan terhadap variabel dependen karena memiliki nilai $<0,05$ dan juga diketahui bahwa profitabilitas bank dapat diprediksi dengan modal bank, ukuran bank, konsentrasi pasar, kepemilikan, inflasi.

Tabel 6. Uji f

\begin{tabular}{clccccc}
\hline \multicolumn{2}{c}{ Model } & Sum of Squares & $\boldsymbol{d f}$ & mean Square & $\boldsymbol{F}$ & Sig. \\
\hline \multirow{2}{*}{1} & Regression & 0,006 & 5 & 0,001 & 26,790 & $0.000^{\mathrm{b}}$ \\
\cline { 2 - 7 } & Residual & 0.008 & 175 & 0,000 & & \\
\cline { 2 - 7 } & Total & 0.014 & 180 & & & \\
\hline
\end{tabular}

Sumber: Data diolah, 2021

\section{Simpulan dan Saran}

Kesimpulan dari pengujian yang telah dilaksanakan adalah sebagai berikut. (1) Modal bank tidak mempunyai pengaruh signifikan terhadap profitabilitas bank. (2) Ukuran bank mempunyai pengaruh positif dan signifikan terhadap profitabilitas bank, yaitu jika ukuran suatu bank besar, profitabilitas bank tersebut juga akan besar. (3) Konsentrasi pasar tidak berpengaruh signifikan terhadap profitabilitas bank. (4) Kepemilikan tidak mempunyai pengaruh signifikan terhadap profitabilitas bank. (5) Inflasi memiliki pengaruh positif dan signifikan terhadap profitabilitas bank, yaitu bank di Indonesia dapat mengantisipasi terjadinya inflasi di masa depan sehingga jika terjadi inflasi maka bank tetap dapat mempertahankan tingkat profitabilitasnya. 
Berdasarkan dari hasil uji dan kesimpulan yang telah ditarik, maka peneliti menganjurkan supaya: (1) Memperluas skala sampel yang diteliti supaya hasil yang didapatkan lebih akurat. (2) Menambahkan variabel yang memberi pengaruh terhadap variabel dependen. (3) Memperluas objek penelitian sehingga mencakup perusahaan perbankan di luar Indonesia.

\section{Daftar Pustaka}

Abbas, A., \& Arizah, A. (2019). Marketability, profitability, and profit-loss sharing: evidence from sharia banking in Indonesia. Asian Journal of Accounting Research. https://doi.org/10.1108/ajar-08-2019-0065

Batten, J. A., \& Xuun Vinh, V. (2017). Determinants of Bank Profitability Evidence from Vietnam. SSRN Electronic Journal, 4(1), 17-45. https://doi.org/10.2139/ssrn.2485023

Bolarinwa, S. T., Obembe, O. B., \& Olaniyi, C. (2019). Re-examining the determinants of bank profitability in Nigeria. Journal of Economic Studies. https://doi.org/10.1108/JES09-2017-0246

Bolarinwa, S. T., \& Soetan, F. (2019). The effect of corruption on bank profitability. Journal of Financial Crime. https://doi.org/10.1108/JFC-09-2018-0102

Bougatef, K. (2017). Determinants of bank profitability in Tunisia: does corruption matter? Journal of Money Laundering Control. https://doi.org/10.1108/JMLC-10-2015-0044

De Haan, J., \& Poghosyan, T. (2012). Bank size, market concentration, and bank earnings volatility in the US. Journal of International Financial Markets, Institutions and Money, 22(1), 35-54. https://doi.org/10.1016/j.intfin.2011.07.002

Ebrahimi, M., Arshadi, A., \& Salimi, M. S. (2016). Effective Factors on Bank Profitability in Iran. In Journal of Money and Economy (Vol. 10, Issue 1, pp. 108-129).

Fathinna, S. D., Rini, I., \& Pengestuti, D. (2016). Pengaruh CAR , NPL , LDR , Growth Deposit dan Bank Variabel Kontrol ( Studi Empiris pada Bank Konvensional yang Terdaftar Pada Bursa Efek Indonesia Periode 2010-2014 ). Diponegoro Journal of Management, 5(3), 1-10.

Gaur, D., \& Mohapatra, D. R. (2020). Non-performing Assets and Profitability: Case of Indian Banking Sector. Vision. https://doi.org/10.1177/0972262920914106

Lee, C. C., \& Hsieh, M. F. (2013). The impact of bank capital on profitability and risk in Asian banking. Journal of International Money and Finance, 32(1), 251-281. https://doi.org/10.1016/j.jimonfin.2012.04.013

Lee, C. C., Ning, S. L., \& Lee, C. C. (2015). How does Bank Capital Affect Bank Profitability and Risk? Evidence from China's WTO Accession. China and World Economy, 23(4), 19-39. https://doi.org/10.1111/cwe.12119

Mohammad Morshedur Rahman, Md. Kowsar Hamid, \& Khan, \&Md. A. M. (2015). SciHub | Determinants of Bank Profitability: Empirical Evidence from Bangladesh. International Journal of Business and Management, 10(8) | 10.5539/ijbm.v10n8p135. International Journal of Business and Management, 10(8). https://scihub.se/10.5539/ijbm.v10n8p135

Ozili, Peterson K. (2018). Banking stability determinants in Africa. International Journal of Managerial Finance, 14(4), 462-483. https://doi.org/10.1108/IJMF-01-2018-0007

Ozili, Peterson Kitakogelu, \& Uadiale, O. (2017). Ownership concentration and bank profitability. Future Business Journal, 3(2), 159-171. https://doi.org/10.1016/j.fbj.2017.07.001

Pinasti, W. F., \& Mustikawati, R. I. (2018). PENGARUH CAR, BOPO, NPL, NIM DAN LDR TERHADAP PROFITABILITAS BANK UMUM PERIODE 2011-2015. Nominal, Barometer Riset Akuntansi Dan Manajemen. https://doi.org/10.21831/nominal.v7i1.19365 
Samad, A. (2015). Determinants Bank Profitability: Empirical Evidence from Bangladesh Commercial Banks. International Journal of Financial Research, 6(3). https://doi.org/10.5430/ijfr.v6n3p173

Tiwu, M. I. H. (2020). PENGARUH PANDEMIC COVID 19 TERHADAP NPL BANK PERKREDITAN RAKYAT DI INDONESIA. Jurnal Akuntansi Transparansi Dan Akuntabilitas, 8(2), 79-87. 